Article

\title{
Briarenols I-K, New Anti-inflammatory 8,17-Epoxybriaranes from the Octocoral Briareum excavatum (Briareidae)
}

\author{
Thanh-Hao Huynh ${ }^{1,2}$, Lee-Shing Fang ${ }^{3,4}$, Yu-Hsin Chen ${ }^{2}$, Bo-Rong Peng ${ }^{2}$, You-Ying Chen ${ }^{2}$, \\ Li-Guo Zheng ${ }^{2}$, Yu-Jen Wu ${ }^{5}$, Zhi-Hong Wen $\left.{ }^{6}{ }^{(}\right)$, Jih-Jung Chen ${ }^{7}{ }^{\circ}$, Tzu-Chi Lin ${ }^{8, *}$ and \\ Ping-Jyun Sung $1,2,6,9,10, * \mathbb{D}$
}

1 Graduate Institute of Marine Biology, National Dong Hwa University, Pingtung 94450, Taiwan; haohuynh0108@gmail.com

2 National Museum of Marine Biology and Aquarium, Pingtung 94450, Taiwan; kb5634@yahoo.com.tw (Y.-H.C.); pengpojung@gmail.com (B.-R.P.); zoeblack0108@gmail.com (Y.-Y.C.); t0919928409@gmail.com (L.-G.Z.)

3 Center for Environmental Toxin and Emerging-Contaminant Research, Cheng Shiu University, Kaohsiung 83347, Taiwan; lsfang@gcloud.csu.edu.tw

4 Super Micro Mass Research and Technology Center, Cheng Shiu University, Kaohsiung 83347, Taiwan

5 Department of Nursing, Meiho University, Pingtung 91202, Taiwan; x00002180@meiho.edu.tw

6 Department of Marine Biotechnology and Resources, National Sun Yat-sen University, Kaohsiung 80424, Taiwan; wzh@mail.nsysu.edu.tw

7 Faculty of Pharmacy, School of Pharmaceutical Sciences, National Yang-Ming University, Taipei 11221, Taiwan; chenjj@ym.edu.tw

8 Department of Emergency Medicine, Antai Medical Care Corporation Antai Tian-Sheng Memorial Hospital, Pingtung 92842, Taiwan

9 Chinese Medicine Research and Development Center, China Medical University Hospital, Taichung 40447, Taiwan

10 Graduate Institute of Natural Products, Kaohsiung Medical University, Kaohsiung 80708, Taiwan

* Correspondence: Bryan1110@hotmail.com (T.-Z.L.); pjsung@nmmba.gov.tw (P.-J.S.); Tel.: +886-8-882-5037 (T.-Z.L.); Fax: +886-8-882-5087 (P.-J.S.)

Received: 7 February 2020; Accepted: 16 March 2020; Published: 19 March 2020

\begin{abstract}
Five 8,17-epoxybriaranes, including three new compounds-briarenols I-K (1-3), along with two known analogues, briaexcavatolide $\mathrm{P}(4)$ and briaexcavatin $\mathrm{P}(5)$, were isolated from the octocoral Briareum excavatum. The structures of briaranes 1-3 were elucidated by spectroscopic methods, including 1D and 2D NMR studies and (+)-HRESIMS. Briarane 4 exerted inhibition effects on inducible nitric oxide synthase (iNOS) and cyclooxygenase-2 (COX-2) release from RAW 264.7.
\end{abstract}

Keywords: Briareum excavatum; briarenol; briarane; anti-inflammatory; iNOS; COX-2

\section{Introduction}

Octocorals of the genus Briareum (family Briareidae) [1-4] are proven to be the most important source to produce briarane-type diterpenoids [5]. The compounds of this type are only found in marine invertebrates, particularly in octocorals and demonstrated a wide spectrum of bioactivities, such as anti-inflammatory activity [6] and cytotoxicity [7]. In our continuing research into the chemical constituents of an octocoral B. excavatum (Nutting 1911), which was distributed extensively in the coral reefs of Taiwan, have resulted in isolation of three previously unreported 8,17-epoxybriaranes-briarenols I-K (1-3) along with two known analogues, briaexcavatolide P (4) [8] and briaexcavatin P (5) [9], 
(Figure 1). In the current study, the comprehensive workflow of isolation, structure determination, and anti-inflammatory activity evaluation, was implemented on briaranes 1-5.

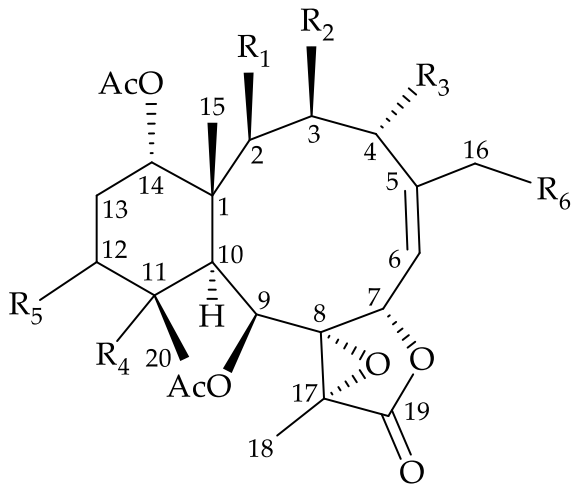

$$
\begin{gathered}
\text { 1: } \mathrm{R}_{1}=\mathrm{OAc}, \mathrm{R}_{2}=\mathrm{R}_{6}=\mathrm{OH}, \mathrm{R}_{3}=n-\mathrm{OC}(\mathrm{O}) \mathrm{Pr}, \mathrm{R}_{4}=\mathrm{H}, \mathrm{R}_{5}=\beta-\mathrm{OH} \\
\text { 2: } \mathrm{R}_{1}=\mathrm{R}_{2}=\mathrm{OH}, \mathrm{R}_{3}=\mathrm{OAc}, \mathrm{R}_{4}=\mathrm{R}_{6}=\mathrm{H}, \mathrm{R}_{5}=\beta-\mathrm{OH} \\
\text { 3: } \mathrm{R}_{1}=\mathrm{OAc}, \mathrm{R}_{2}=\mathrm{R}_{3}=\mathrm{R}_{6}=\mathrm{H}, \mathrm{R}_{4}=\mathrm{OH}, \mathrm{R}_{5}=\beta-\mathrm{OH} \\
\text { 4: } \mathrm{R}_{1}=\mathrm{OAc}, \mathrm{R}_{2}=\mathrm{OH}, \mathrm{R}_{3}=n-\mathrm{OC}(\mathrm{O}) \mathrm{Pr}, \mathrm{R}_{4}=\mathrm{R}_{6}=\mathrm{H}, \mathrm{R}_{5}=\beta-\mathrm{OH} \\
\text { 5: } \mathrm{R}_{1}=\mathrm{R}_{3}=\mathrm{OAc}, \mathrm{R}_{2}=\mathrm{OH}, \mathrm{R}_{4}=\mathrm{R}_{6}=\mathrm{H}, \mathrm{R}_{5}=\beta-\mathrm{OH} \\
\text { 6: } \mathrm{R}_{1}=\mathrm{OAc}, \mathrm{R}_{2}=n-\mathrm{OC}(\mathrm{O}) \mathrm{Pr}, \mathrm{R}_{3}=\mathrm{R}_{4}=\mathrm{R}_{6}=\mathrm{H}, \mathrm{R}_{5}=\beta-\mathrm{OH} \\
\text { 7: } \mathrm{R}_{1}=\mathrm{OAc}, \mathrm{R}_{2}=\mathrm{R}_{3}=\mathrm{R}_{6}=\mathrm{H}, \mathrm{R}_{4}=\mathrm{OH}, \mathrm{R}_{5}=\alpha-\mathrm{OH}
\end{gathered}
$$

Figure 1. Structures of briarenols I-K (1-3), briaexcavatolide P (4), briaexcavatin P (5), excavatolide B (6), and briareolide B (7).

\section{Results and Discussion}

Briarenol I (1) was isolated as an amorphous powder and displayed a sodiated adduct ion at $\mathrm{m} / \mathrm{z}$ 649.24677 in the (+)-HRESIMS, which indicated its molecular formula was $\mathrm{C}_{30} \mathrm{H}_{42} \mathrm{O}_{14}$ (calculated for $\mathrm{C}_{30} \mathrm{H}_{42} \mathrm{O}_{14}+\mathrm{Na}, 649.24668$; unsaturation degrees $\left.=10\right)$. The IR spectrum revealed absorptions for hydroxy $\left(v_{\max } 3524 \mathrm{~cm}^{-1}\right), \gamma$-lactone $\left(v_{\max } 1783 \mathrm{~cm}^{-1}\right)$, and ester carbonyl $\left(v_{\max } 1736 \mathrm{~cm}^{-1}\right)$ moieties. Resonances in the ${ }^{13} \mathrm{C}$ NMR of 1 at $\delta_{C} 172.9,172.3,170.5,170.0$, and $170.0(5 \times C)$ supported the presence of a $\gamma$-lactone and four esters (Table 1). Three of the esters were identified as acetates by the presence of three methyl singlet resonances in the ${ }^{1} \mathrm{H}$ NMR spectrum at $\delta_{\mathrm{H}} 2.34,2.15$, and 2.08 (Table 2) and the remaining ester was found to be an $n$-butyroxy group based on ${ }^{1} \mathrm{H}$ NMR studies, including a correlation spectroscopy (COSY) experiment, which revealed seven contiguous protons $\left(\delta_{\mathrm{H}} 2.30,2 \mathrm{H}, \mathrm{t}, J=7.2 \mathrm{~Hz} ; 1.63,2 \mathrm{H}, \mathrm{tq}, J=7.2 \mathrm{~Hz} ; 0.95,3 \mathrm{H}, \mathrm{t}, J=7.2 \mathrm{~Hz}\right)$. From the COSY spectrum (Figure 2), the proton sequences from H-6/H-7, H-9/H-10/H-11/H-12/H $-13 / \mathrm{H}-14$, and H-11/ $\mathrm{H}_{3}-20$ were established. The hydroxy proton signals at $\delta_{\mathrm{H}} 4.30(1 \mathrm{H}, \mathrm{d}, J=12.0 \mathrm{~Hz}), 1.49(1 \mathrm{H}, \mathrm{d}, J=4.0 \mathrm{~Hz})$, and $3.49(1 \mathrm{H}, \mathrm{dd}, J=9.6,4.4 \mathrm{~Hz})$ were found to correlate with $\mathrm{H}-3\left(\delta_{\mathrm{H}} 4.59, \mathrm{~d}, J=12.0 \mathrm{~Hz}\right), \mathrm{H}-12\left(\delta_{\mathrm{H}} 4.10\right.$, $\mathrm{m})$, and $\mathrm{H}_{2}-16\left(\delta_{\mathrm{H}} 4.35,1 \mathrm{H}, \mathrm{dd}, J=13.6,4.4 \mathrm{~Hz} ; 4.04,1 \mathrm{H}, \mathrm{dd}, J=13.6,9.6 \mathrm{~Hz}\right)$, respectively. Thus, the hydroxy groups should be positioned at C-3, C-12, and C-16, respectively. Olefinic resonances in the ${ }^{13} \mathrm{C}$ NMR at $\delta_{\mathrm{C}} 125.5(\mathrm{CH}-6)$ and $142.0(\mathrm{C}-5)$ indicated the presence of a trisubstituted carbon-carbon double bond. On the basis of these data and the heteronuclear multiple bond correlation (HMBC) experiment (Figure 2), the connectivity from C-1 to C-14 was established. A hydroxymethyl group at C-5 was revealed by the HMBC between C-16 oxymethylene protons to C-4, C-5, and C-6. The C-15 methyl group at C-1 was confirmed by the HMBC between $\mathrm{H}_{3}-15 / \mathrm{C}-1, \mathrm{C}-2, \mathrm{C}-10, \mathrm{C}-14$, and H-10/C-15. The $n$-butyrate positioned at C-4 was confirmed from the connectivity between $\mathrm{H}-4\left(\delta_{\mathrm{H}} 6.14\right)$ and the carbonyl carbon of $n$-butyrate group $\left(\delta_{\mathrm{C}} 172.3\right)$. HMBC from the oxymethine protons at $\delta_{\mathrm{H}} 4.53(\mathrm{H}-2)$, $5.32(\mathrm{H}-9)$, and $4.88(\mathrm{H}-14)$ to the acetate carbonyls at $\delta_{\mathrm{C}} 172.9,170.0$, and 170.0, placed the acetoxy groups on C-2, C-9, and C-14, respectively. Thirteen of the fourteen oxygen atoms in the molecular formula of 1 could be accounted for from the presence of a $\gamma$-lactone, four esters, and three hydroxy groups. The remaining oxygen atom had to be placed between C-8 and C-17 to form a tetrasubstituted epoxide based on the ${ }^{13} \mathrm{C}$ NMR evidences at $\delta_{\mathrm{C}} 70.8(\mathrm{C}-8)$ and $62.5(\mathrm{C}-17)$ and the ${ }^{1} \mathrm{H}$ NMR chemical shift of a tertiary methyl at $\delta_{\mathrm{H}} 1.66\left(3 \mathrm{H}, \mathrm{s}, \mathrm{H}_{3}-18\right)$. 
Table 1. ${ }^{13} \mathrm{C}$ NMR $\left(\delta_{\mathrm{C}} 100 \mathrm{MHz}, \mathrm{CDCl}_{3}\right)$ data for briaranes 1-3.

\begin{tabular}{|c|c|c|c|}
\hline Position & 1 & 2 & 3 \\
\hline 1 & $43.3, \mathrm{C}^{\mathrm{a}}$ & 43.7, C & $47.7, \mathrm{C}$ \\
\hline 2 & $87.4, \mathrm{CH}$ & $85.6, \mathrm{CH}$ & $74.9, \mathrm{CH}$ \\
\hline 3 & $73.1, \mathrm{CH}$ & $73.6, \mathrm{CH}$ & $31.6, \mathrm{CH}_{2}$ \\
\hline 4 & $66.0, \mathrm{CH}$ & $65.9, \mathrm{CH}$ & $28.4, \mathrm{CH}_{2}$ \\
\hline 5 & $142.0, \mathrm{C}$ & $139.3, \mathrm{C}$ & $144.8, \mathrm{C}$ \\
\hline 6 & $125.5, \mathrm{CH}$ & $124.3, \mathrm{CH}$ & $118.4, \mathrm{CH}$ \\
\hline 7 & $74.1, \mathrm{CH}$ & $74.0, \mathrm{CH}$ & $74.9, \mathrm{CH}$ \\
\hline 8 & $70.8, \mathrm{C}$ & $69.9, \mathrm{C}$ & $70.8, \mathrm{C}$ \\
\hline 9 & $66.2, \mathrm{CH}$ & $67.1, \mathrm{CH}$ & $67.4, \mathrm{CH}$ \\
\hline 10 & $40.5, \mathrm{CH}$ & $41.4, \mathrm{CH}$ & $49.0, \mathrm{CH}$ \\
\hline 11 & $37.2, \mathrm{CH}$ & $36.4, \mathrm{CH}$ & $78.2, \mathrm{C}$ \\
\hline 12 & $66.6, \mathrm{CH}$ & $67.0, \mathrm{CH}$ & $73.4, \mathrm{CH}$ \\
\hline 13 & $30.2, \mathrm{CH}_{2}$ & $30.4, \mathrm{CH}_{2}$ & $30.2, \mathrm{CH}_{2}$ \\
\hline 14 & $80.5, \mathrm{CH}$ & $80.1, \mathrm{CH}$ & $74.8, \mathrm{CH}$ \\
\hline 15 & $18.6, \mathrm{CH}_{3}$ & $19.1, \mathrm{CH}_{3}$ & $14.3, \mathrm{CH}_{3}$ \\
\hline 16 & $62.5, \mathrm{CH}_{2}$ & $16.8, \mathrm{CH}_{3}$ & $27.2, \mathrm{CH}_{3}$ \\
\hline 17 & $62.5, \mathrm{C}$ & $61.8, \mathrm{C}$ & $66.5, \mathrm{C}$ \\
\hline 18 & $10.3, \mathrm{CH}_{3}$ & $10.3, \mathrm{CH}_{3}$ & $10.4, \mathrm{CH}_{3}$ \\
\hline 19 & $170.5, \mathrm{C}$ & $170.9, \mathrm{C}$ & $170.4, C$ \\
\hline 20 & $8.9, \mathrm{CH}_{3}$ & $8.7, \mathrm{CH}_{3}$ & 16.9, $\mathrm{CH}_{3}$ \\
\hline \multirow[t]{2}{*}{ OAc-2 } & $172.9, \mathrm{C}$ & & $170.2, \mathrm{C}$ \\
\hline & $21.2, \mathrm{CH}_{3}$ & & $21.2, \mathrm{CH}_{3}$ \\
\hline \multirow[t]{2}{*}{ OAc-4 } & & $169.5, \mathrm{C}$ & \\
\hline & & $21.0, \mathrm{CH}_{3}$ & \\
\hline \multirow[t]{2}{*}{ OAc-9 } & $170.0, \mathrm{C}$ & $169.2, \mathrm{C}$ & $168.1, \mathrm{C}$ \\
\hline & $21.5, \mathrm{CH}_{3}$ & $21.1, \mathrm{CH}_{3}$ & $21.5, \mathrm{CH}_{3}$ \\
\hline \multirow[t]{2}{*}{ OAc-14 } & $170.0, \mathrm{C}$ & $170.0, \mathrm{C}$ & $170.4, \mathrm{C}$ \\
\hline & $21.2, \mathrm{CH}_{3}$ & $21.0, \mathrm{CH}_{3}$ & 21.3, $\mathrm{CH}_{3}$ \\
\hline \multirow[t]{4}{*}{$n-\mathrm{OC}(\mathrm{O}) \mathrm{Pr}-4$} & $172.3, \mathrm{C}$ & & \\
\hline & $35.9, \mathrm{CH}_{2}$ & & \\
\hline & $18.2, \mathrm{CH}_{2}$ & & \\
\hline & $13.7, \mathrm{CH}_{3}$ & & \\
\hline
\end{tabular}
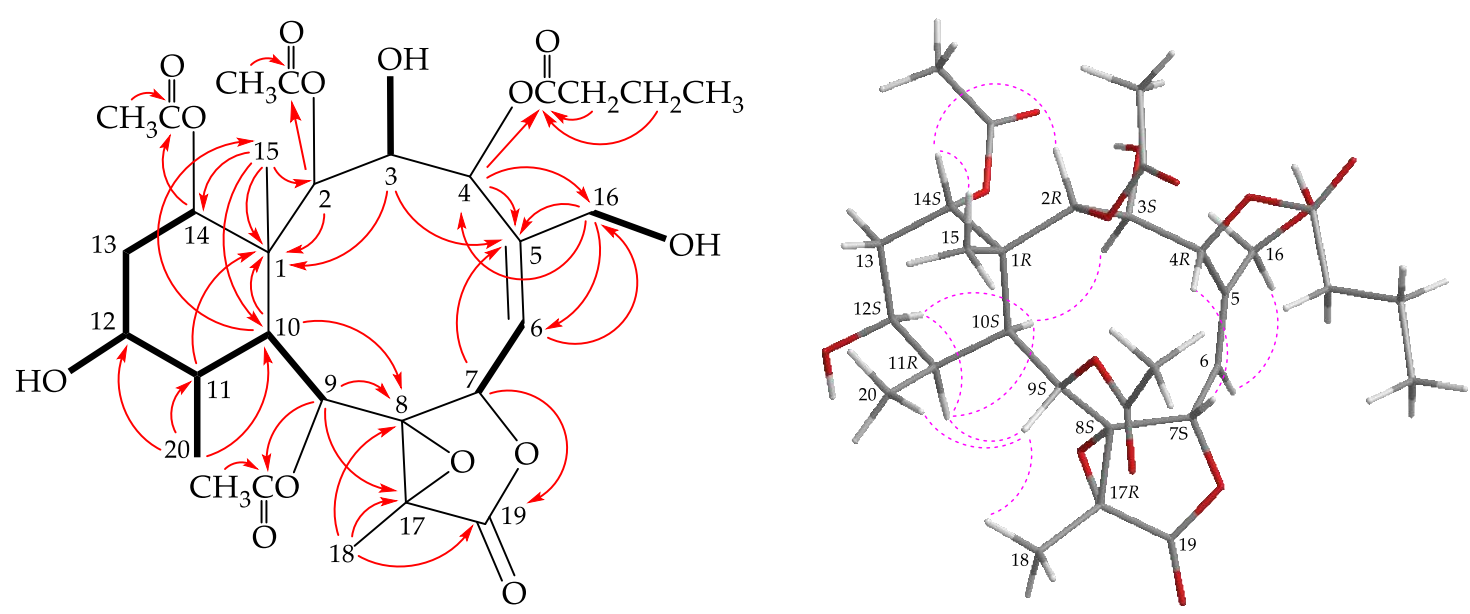

Figure 2. The COSY $(-)$ correlations, selective HMBC $(\sim)$, and protons with key NOESY correlations $(\cdots)$ of $\mathbf{1}$ 
Table 2. ${ }^{1} \mathrm{H}$ NMR $\left(\delta_{\mathrm{H}}, 400 \mathrm{MHz}\right.$ in $\left.\mathrm{CDCl}_{3}\right)$ data $(J$ in $\mathrm{Hz})$ for briaranes 1-3.

\begin{tabular}{|c|c|c|c|}
\hline Position & 1 & 2 & 3 \\
\hline 2 & $4.53 \mathrm{~s}$ & $3.45 \mathrm{~d}(10.4)$ & $5.13 \mathrm{~d}(8.4)$ \\
\hline $3 \alpha / \beta$ & $4.59 \mathrm{~d}(12.0)$ & $4.27 \mathrm{~d}(10.4)$ & $1.67 \mathrm{~m} ; 2.60 \mathrm{ddd}(16.0,14.8,6.0)$ \\
\hline $4 / 4^{\prime}$ & $6.14 \mathrm{~s}$ & $6.05 \mathrm{~d}(1.2)$ & $2.48 \mathrm{br} \mathrm{d}(16.0) ; 1.90 \mathrm{~m}$ \\
\hline 6 & $5.53 \mathrm{~d}(6.0)$ & $5.29 \mathrm{dq}(6.4,1.6)$ & $5.19 \mathrm{~s}$ \\
\hline 7 & $5.62 \mathrm{~d}(6.0)$ & $5.71 \mathrm{~d}(6.4)$ & $5.19 \mathrm{~s}$ \\
\hline 9 & $5.32 \mathrm{~d}(8.8)$ & $5.26 \mathrm{~d}(9.2)$ & $5.78 \mathrm{~d}(1.2)$ \\
\hline 10 & $2.64 \mathrm{dd}(8.8,4.8)$ & $2.55 \mathrm{dd}(9.2,5.2)$ & $2.14 \mathrm{br} \mathrm{s}$ \\
\hline 11 & $2.41 \mathrm{~m}$ & $2.47 \mathrm{~m}$ & \\
\hline 12 & $4.10 \mathrm{~m}$ & $4.05 \mathrm{~m}$ & $3.72 \mathrm{dd}(12.4,4.8)$ \\
\hline $13 \alpha / \beta$ & $1.75 \mathrm{~m} ; 2.01 \mathrm{~m}$ & $1.69 \mathrm{~m} ; 2.00 \mathrm{~m}$ & $1.67 \mathrm{~m} ; 2.04 \mathrm{~m}$ \\
\hline 14 & $4.88 \mathrm{dd}(2.8,2.8)$ & $4.92 \mathrm{dd}(2.8,2.8)$ & $4.79 \mathrm{dd}(2.4,2.0)$ \\
\hline 15 & $0.99 \mathrm{~s}$ & 0.99 br s & $1.21 \mathrm{~s}$ \\
\hline $16 a / b$ & $4.35 \mathrm{dd}(13.6,4.4) ; 4.04 \mathrm{dd}(13.6,9.6)$ & $1.89 \mathrm{br} \mathrm{s}$ & $1.99 \mathrm{~s}$ \\
\hline 18 & $1.66 \mathrm{~s}$ & $1.66 \mathrm{~s}$ & $1.77 \mathrm{~s}$ \\
\hline 20 & $1.12 \mathrm{~d}(6.8)$ & $1.07 \mathrm{~d}(7.2)$ & $1.15 \mathrm{~s}$ \\
\hline $\mathrm{OH}-2$ & & $2.79 \mathrm{~d}(10.4)$ & \\
\hline $\mathrm{OH}-3$ & $4.30 \mathrm{~d}(12.0)$ & $2.87 \mathrm{~d}(10.4)$ & \\
\hline $\mathrm{OH}-12$ & $1.49 \mathrm{~d}(4.0)$ & $1.43 \mathrm{~d}(4.0)$ & - \\
\hline OH-16 & $3.49 \mathrm{dd}(9.6,4.4)$ & & \\
\hline OAc-2 & $2.08 \mathrm{~s}$ & & $2.00 \mathrm{~s}$ \\
\hline OAc-4 & & $2.14 \mathrm{~s}$ & \\
\hline OAc-9 & $2.34 \mathrm{~s}$ & $2.32 \mathrm{~s}$ & $2.22 \mathrm{~s}$ \\
\hline OAc-14 & $2.15 \mathrm{~s}$ & $2.16 \mathrm{~s}$ & $2.03 \mathrm{~s}$ \\
\hline \multirow{3}{*}{$n$-OC(O)Pr-4 } & $0.95 \mathrm{t}(7.2)$ & & \\
\hline & $1.63 \mathrm{tq}(7.2)$ & & \\
\hline & $2.30 \mathrm{t}(7.2)$ & & \\
\hline
\end{tabular}

The stereochemistry of $\mathbf{1}$ was deduced from an NOESY experiment (Figure 2) and biogenetic considerations. The NOE correlations of $\mathrm{H}-10 / \mathrm{H}-11, \mathrm{H}-10 / \mathrm{H}-12$, and $\mathrm{H}-11 / \mathrm{H}-12$ indicated that these protons were situated on the same face of the structure and were assigned as the $\alpha$ protons since the $\mathrm{C}-15$ methyl is the $\beta$-substituent at C-1. The NOE correlation between $\mathrm{H}_{3}-15$ and $\mathrm{H}-14$ implied that $\mathrm{H}-14$ had a $\beta$-orientation. $\mathrm{H}-3$ exhibited a correlation with $\mathrm{H}-10$, and, as well as a lack of coupling constants were detected between $\mathrm{H}-2 / \mathrm{H}-3$ and $\mathrm{H}-3 / \mathrm{H}-4$, indicating the dihedral angles between $\mathrm{H}-2 / \mathrm{H}-3$ and $\mathrm{H}-3 / \mathrm{H}-4$ were approximately $90^{\circ}$ and the 2-acetoxy, 3 -hydroxy, and $4-n$-butyroxy groups were $\beta$-, $\beta-$, and $\alpha$-oriented, respectively. A correlation from $\mathrm{H}-4$ to $\mathrm{H}-7$, suggested that $\mathrm{H}-7$ was $\beta$-oriented. The Z-configuration of C-5/6 double bond was confirmed based on the fact that the C-6 olefinic proton $\left(\delta_{\mathrm{H}} 5.53\right)$ correlated to one of the C-16 hydroxymethyl protons $\left(\delta_{\mathrm{H}} 4.04\right)$. H-9 was found to correlate with $\mathrm{H}-11, \mathrm{H}_{3}-18$, and $\mathrm{H}_{3}-20$. From a consideration of molecular model, $\mathrm{H}-9$ was found to be reasonably close to $\mathrm{H}-11, \mathrm{H}_{3}-18$, and $\mathrm{H}_{3}-20$, thus, $\mathrm{H}-9$ should be placed on the $\alpha$ face, and Me- 18 was $\beta$-oriented in the $\gamma$-lactone moiety, and the 8,17-epoxy group should be $\alpha$-oriented. It was found that the NMR signals of $\mathbf{1}$ were similar to those of a known briarane, briaexcavatolide P (4) (Figure 1) [8], except that the signals corresponding to the Me-16 vinyl methyl in 4 were replaced by signals for a hydroxymethyl group in 1. Additionally, as briaranes 1-5 were isolated along with a known briarane, excavatolide B (6) $[6,10,11]$ from the same target organism, B. excavatum, and the absolute configuration of 6 was determined by a single-crystal $X$-ray diffraction analysis $[6,11]$. Therefore, on biogenetic grounds to assume that briaranes 1-5 had the same absolute stereochemistry as that of $\mathbf{6}$, tentatively, and the configurations of stereogenic carbons of 1 were determined as $1 R, 2 R, 3 S, 4 R, 7 S, 8 S, 9 S, 10 S, 11 R, 12 S, 14 S$, and $17 R$ (Supplementary Materials, Figures S1-S10).

Briarenol J (2) had a molecular formula $\mathrm{C}_{26} \mathrm{H}_{36} \mathrm{O}_{12}$ by its (+)-HRESIMS at $m / z 563.21007$ (calculated for $\left.\mathrm{C}_{26} \mathrm{H}_{36} \mathrm{O}_{12}+\mathrm{Na}, 563.20990\right)$. The IR spectrum showed bands at 3483, 1779, and $1727 \mathrm{~cm}^{-1}$, consistent with the presence of hydroxy, $\gamma$-lactone, and ester groups, respectively, in 2 . From the ${ }^{13} \mathrm{C}$ and DEPT data (Table 2), one trisubstituted double bond was deduced from the signals of two carbons at $\delta_{\mathrm{C}} 139.3$ (C-5) and 124.3 (CH-6). A methyl-containing tetrasubstituted epoxy group was confirmed from the signals of two oxygenated quaternary carbons at $\delta_{C} 69.9$ (C-8) and $61.8(\mathrm{C}-17)$, and from the 
chemical shift of a tertiary methyl $\left(\delta_{\mathrm{H}} 1.66,3 \mathrm{H}, \mathrm{s} ; \delta_{\mathrm{C}} 10.3, \mathrm{CH}_{3}-18\right.$; Tables 1 and 2$)$. Four carbonyl resonances at $\delta_{C} 170.9,170.0,169.5$, and 169.2 in the ${ }^{13} \mathrm{C}$ spectrum confirmed the presence of a $\gamma$-lactone and three esters. All the esters were identified as acetates by the presence of three methyl singlet resonances in the ${ }^{1} \mathrm{H}$ NMR spectrum at $\delta_{\mathrm{H}} 2.32,2.16$, and 2.14, respectively.

Coupling constants information in the COSY spectrum of 2 enabled identification of $\mathrm{H}-6 / \mathrm{H}-7$, $\mathrm{H}-9 / \mathrm{H}-10 / \mathrm{H}-11 / \mathrm{H}-12 / \mathrm{H}_{2}-13 / \mathrm{H}-14, \mathrm{H}-11 / \mathrm{H}_{3}-20$, and $\mathrm{H}-6 / \mathrm{H}_{3}-16$ (by allylic coupling; Figure 3), these data, together with the HMBC experiment (Figure 3), the molecular framework of 2 could be established. The HMBC also indicated that the acetoxy groups should be attached at C-4, C-9, and C-14, respectively. Thus, the remaining hydroxy groups have to be positioned at $\mathrm{C}-2, \mathrm{C}-3$, and $\mathrm{C}-12$, as indicated by the COSY correlations between $\mathrm{H}-2 / \mathrm{OH}-2, \mathrm{H}-3 / \mathrm{OH}-3$, and $\mathrm{H}-12 / \mathrm{OH}-12$.
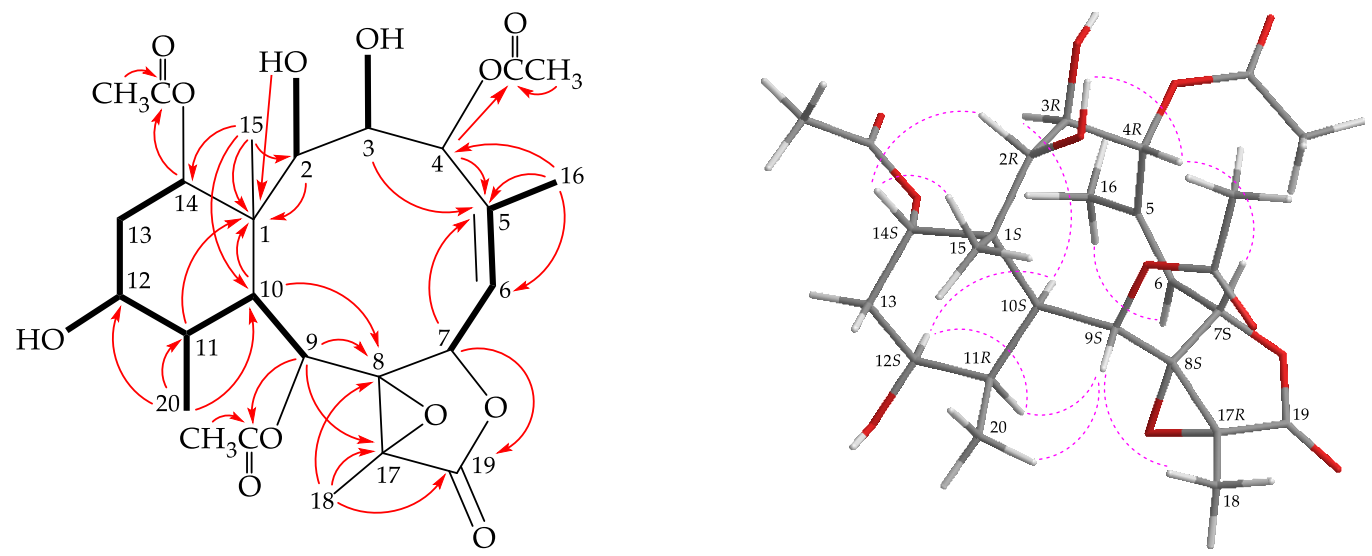

Figure 3. The COSY ( - ) correlations, selective $\operatorname{HMBC}(\sim)$, and protons with key NOESY correlations $(\cdots)$ of 2 .

The stereochemistry of 2 was elucidated from the NOE interactions observed in a NOESY experiment (Figure 3 ) and by the vicinal ${ }^{1} \mathrm{H}-{ }^{1} \mathrm{H}$ coupling constant analysis. In the NOESY spectrum, correlations were observed between $\mathrm{H}-10$ with $\mathrm{H}-3$ and $\mathrm{H}-12$; and $\mathrm{H}-12$ correlated with $\mathrm{H}-11$, indicating that these protons should be $\alpha$-oriented. $\mathrm{H}-14$ gave a correlation with $\mathrm{H}_{3}-15$, confirming the $\beta$-orientation for this proton. $\mathrm{H}-2$ showed a correlation with $\mathrm{H}-14$, and a lack of coupling constant was detected between $\mathrm{H}-2 / \mathrm{H}-3$, indicating the dihedral angle between $\mathrm{H}-2 / \mathrm{H}-3$ is approximately $90^{\circ}$ and the 2-hydroxy group was $\beta$-oriented. H-4 exhibited correlations with H-7 and 2-hydroxy proton, confirming the $\beta$-orientations for $\mathrm{H}-4$ and $\mathrm{H}-7$. H-9 was found to show correlations with $\mathrm{H}-11, \mathrm{H}_{3}-18$, and $\mathrm{H}_{3}-20$, and from molecular models, $\mathrm{H}-9$ and $\mathrm{H}_{3}-18$ should be placed on the $\alpha$ - and $\beta$-face, respectively. The Z-configuration of C-5/C- 6 double bond was elucidated by a correlation between $\mathrm{H}-6$ and $\mathrm{H}_{3}-16$. The NMR data of 2 were found to be similar to those of a known briarane, briaexcavatin P (5) [9]. It was found that the 2-acetoxy substituent in $\mathbf{5}$ was replaced by a hydroxy group in 2. By comparison of the proton and carbon chemical shifts, coupling constants, NOESY correlations, and rotation value of $\mathbf{2}$ with those of $\mathbf{5}$, the stereochemistry of $\mathbf{2}$ was confirmed to be the same as that of $\mathbf{5}$, and the configurations of the stereogenic centers of 2 were assigned as $1 S, 2 R, 3 R, 4 R$, $7 S, 8 S, 9 S, 10 S, 11 R, 12 S, 14 S$, and 17R (Supplementary Materials, Figures S11-S20).

Briarane 3 (briarenol $\mathrm{K}$ ) was found to have a molecular formula of $\mathrm{C}_{26} \mathrm{H}_{36} \mathrm{O}_{11}$ based on its (+)-HRESIMS peak at $m / z 547.21514$ (calculated for $\mathrm{C}_{26} \mathrm{H}_{36} \mathrm{O}_{11}+\mathrm{Na}, 547.21498$ ). Its absorption peaks in the IR spectrum showed ester carbonyl, $\gamma$-lactone, and broad $\mathrm{OH}$ stretching at 1739, 1780, and $3468 \mathrm{~cm}^{-1}$, respectively. The ${ }^{13} \mathrm{C}$ NMR spectrum indicated that three esters and a $\gamma$-lactone were present, as carbonyl resonances were observed at $\delta_{C} 168.1,170.2,170.4$, and 170.4, respectively (Table 1 ). The ${ }^{1} \mathrm{H}$ NMR data also indicated that presence of three acetate methyls at $\delta_{\mathrm{H}} 2.22,2.03$, and 2.00 (each $3 \mathrm{H} \times \mathrm{s}$; Table 2). It was found that the spectroscopic data of 3 were similar to those of a known briarane, briareolide $\mathrm{B}(7)$ [12]; however, by comparison of the ${ }^{1} \mathrm{H}$ and ${ }^{13} \mathrm{C}$ NMR chemical shifts of $\mathrm{CH}-12$ oxymethine $\left(\delta_{\mathrm{H}} 3.72,1 \mathrm{H}, \mathrm{dd}, J=12.4,4.8 \mathrm{~Hz} ; \delta_{\mathrm{C}} 73.4\right), \mathrm{CH}_{2}-13 \mathrm{sp}^{3}$ methylene $\left(\delta_{\mathrm{H}} 1.67,1 \mathrm{H}\right.$, 
$\left.\mathrm{m} ; 2.04,1 \mathrm{H}, \mathrm{m} ; \delta_{\mathrm{C}} 30.2\right)$, C-11 oxygenated quaternary carbon $\left(\delta_{\mathrm{C}} 78.2\right)$, and Me-20 tertiary methyl $\left(\delta_{\mathrm{H}} 1.15,3 \mathrm{H}, \mathrm{s} ; \delta_{\mathrm{C}} 16.9\right)$ of 3 with those of $7\left(\delta_{\mathrm{H}} 3.56,1 \mathrm{H}, \mathrm{m} ; \delta_{\mathrm{C}} 73.9, \mathrm{CH}-12 ; \delta_{\mathrm{H}} 2.03,1 \mathrm{H}, \mathrm{m} ; 2.12\right.$, $\left.1 \mathrm{H}, \mathrm{m} ; \delta_{\mathrm{C}} 27.6, \mathrm{CH}_{2}-13 ; \delta_{\mathrm{C}} 74.7, \mathrm{C}-11 ; \delta_{\mathrm{H}} 1.16,3 \mathrm{H}, \mathrm{s} ; \delta_{\mathrm{C}} 22.5, \mathrm{Me}-20\right)$ [12] showed that the hydroxy group at $\mathrm{C}-12$ in 3 was $\beta$-oriented. The locations of the functional groups were further confirmed by other HMBC and COSY correlations (Figure 4), and hence briarenol K was assigned the structure of 3. The NOESY spectrum exhibited a correlation from $\mathrm{H}-10$ to $\mathrm{H}-12$, further supporting that $\mathrm{H}-12$ was $\alpha$-oriented and the stereogenic centers of 3 were assigned as $1 S, 2 S, 7 S, 8 S, 9 S, 10 S, 11 S, 12 S, 14 S$, and $17 R$, by the correlations observed in a NOESY spectrum (Figure 4) and this compound was found to be the 12-epimer of briareolide B (7) [12] (Supplementary Materials, Figures S21-S30).
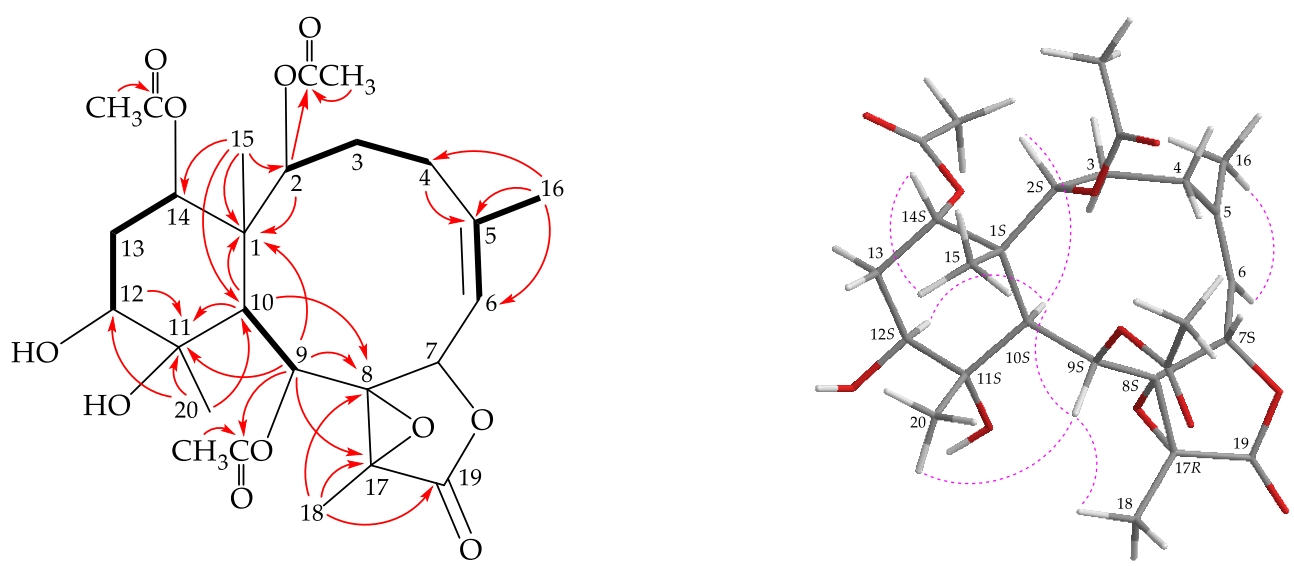

Figure 4. The COSY ( - ) correlations, selective $\operatorname{HMBC}(\sim)$, and protons with key NOESY correlations $(\cdots)$ of 3 .

The inhibition effects of briaranes 1-5 on the release of inducible nitric oxide synthase (iNOS) and cyclooxygenase-2 (COX-2) protein from lipopolysaccharides (LPS)-stimulated RAW 264.7 were assessed. The results showed that briarane 4 reduced the release of iNOS and COX-2 to $35.37 \%$ and $54.61 \%$ at a concentration of $10 \mu \mathrm{M}$, respectively (Figure 5 and Table 3). Briarane 1 was found to be weaker than those of 4 in term of reducing the expression of iNOS and COX-2, indicating that the hydroxy group at C-16 in $\mathbf{1}$ reduced the activity.
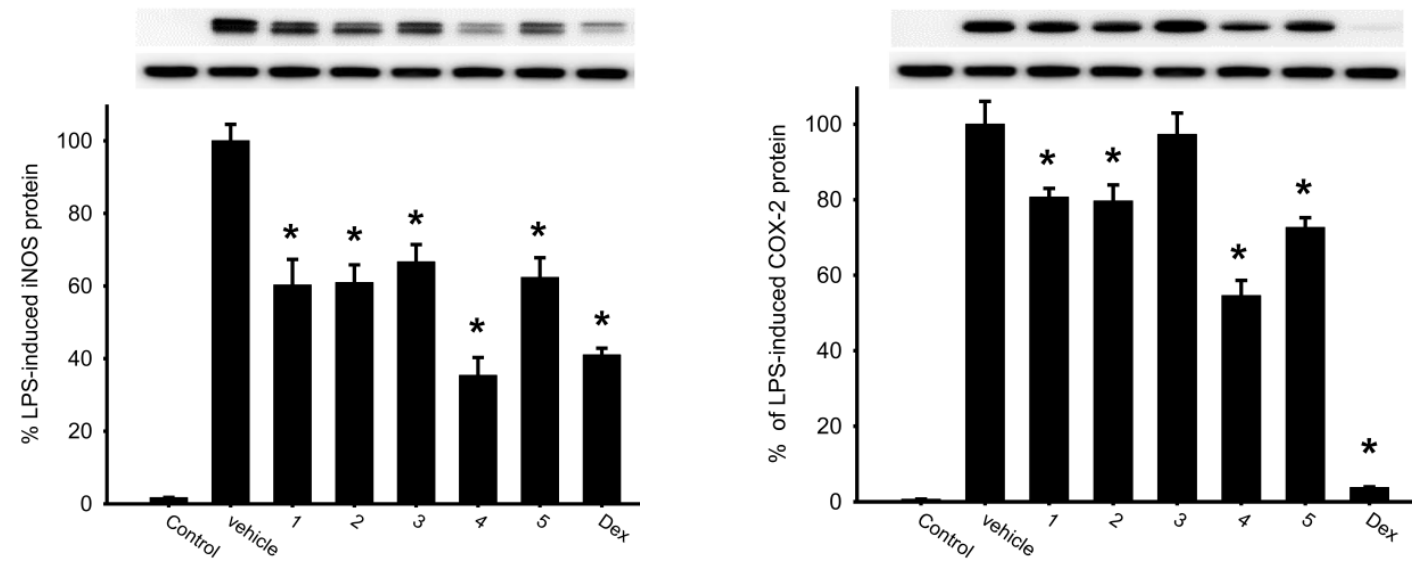

Figure 5. Western blotting showed that briarane 4 downregulated the expression of iNOS and COX-2. Data were normalized to the cells treated with LPS only, and cells treated with dexamethasone (Dex; $10 \mu \mathrm{M})$ were used as a positive control. Data are expressed as the mean $\pm \operatorname{SEM}(n=2 \sim 4)$. Significantly different from cells treated with LPS $(p<0.05)$. 
Table 3. Effects of briaranes 1-5 on LPS-induced pro-inflammatory iNOS and COX-2 protein expression in macrophages.

\begin{tabular}{ccccc}
\hline & iNOS & COX-2 & $\beta$-Actin & \\
\cline { 2 - 4 } & Expression (\% of LPS) & Expression (\% of LPS) & Expression (\% of LPS) & $n$ \\
\hline Negative Control & $1.71 \pm 0.13$ & $0.62 \pm 0.09$ & $120.48 \pm 1.28$ & 2 \\
LPS & $100.00 \pm 4.53$ & $100.00 \pm 6.05$ & $100.00 \pm 3.09$ & 4 \\
1 & $60.27 \pm 7.05$ & $80.63 \pm 2.32$ & $100.29 \pm 2.46$ & 4 \\
2 & $60.94 \pm 4.89$ & $79.65 \pm 4.27$ & $98.29 \pm 3.35$ & 4 \\
3 & $66.64 \pm 4.79$ & $97.28 \pm 5.66$ & $100.49 \pm 6.44$ & 4 \\
4 & $35.37 \pm 4.94$ & $54.61 \pm 4.03$ & $104.56 \pm 2.83$ & 4 \\
5 & $62.36 \pm 5.42$ & $72.63 \pm 2.6$ & $104.79 \pm 2.76$ & 4 \\
Dexamethasone & $41.00 \pm 2.63$ & $3.73 \pm 0.35$ & $104.24 \pm 5.82$ & 2 \\
\hline
\end{tabular}

Data were normalized to those of cells treated with LPS alone, and cells treated with dexamethasone were used as a positive control. Data are expressed as the mean \pm SEM $(n=2-4)$.

\section{Materials and Methods}

\subsection{General Experimental Procedures}

Optical rotation values were measured using a Jasco P-1010 digital polarimeter (Japan Spectroscopic, Tokyo, Japan). IR spectra were measured on a Thermo Scientific Nicolet iS5 FT-IR spectrophotometer (Waltham, MA, USA). NMR spectra were taken on a Jeol Resonance ECZ 400 $\mathrm{S}$ NMR spectrometer (Tokyo, Japan), using the residual $\mathrm{CHCl}_{3}$ signal $\left(\delta_{\mathrm{H}} 7.26 \mathrm{ppm}\right)$ and $\mathrm{CDCl}_{3}$ $\left(\delta_{\mathrm{C}} 77.1 \mathrm{ppm}\right)$ as the internal standard for ${ }^{1} \mathrm{H}$ and ${ }^{13} \mathrm{C}$ NMR, respectively; coupling constants $(J)$ are presented in Hz. ESIMS and HRESIMS were recorded using a Bruker 7 Tesla solariX FTMS system. Column chromatography was carried out with silica gel (230-400 mesh, Merck, Darmstadt, Germany). TLC was performed on plates precoated with Kieselgel $60 \mathrm{~F}_{254}(0.25$-mm-thick, Merck, Darmstadt, Germany), then sprayed with $10 \% \mathrm{H}_{2} \mathrm{SO}_{4}$ solution followed by heating to visualize the spots. Normal-phase HPLC (NP-HPLC) was performed using a system comprised of a Hitachi L-7100 pump (Tokyo, Japan) and a Rheodyne 7725i injection port (Rohnert Park, CA, USA). Reverse-phase HPLC (RP-HPLC) was performed using a system comprised of a Hitachi L-2130 pump (Tokyo, Japan), a Hitachi L-2455 photodiode array detector (Tokyo, Japan), and a Rheodyne 7725i injection port (Rohnert Park, CA, USA). A semipreparative normal-phase column (YMC-Pack SIL, S-5 $\mu \mathrm{m}, 250 \mathrm{~mm} \times$ $20 \mathrm{~mm}$, Sigma-Aldrich, St. Louis, MO, USA) was used for NP-HPLC. A semipreparative reverse-phase column (Luna, $5 \mu \mathrm{m}, \mathrm{C} 18(2) 100 \AA$, AXIA Packed, $250 \mathrm{~mm} \times 21.2 \mathrm{~mm}$; Phenomenex, Torrance, CA, USA) was used for RP-HPLC.

\subsection{Animal Material}

Specimens of B. excavatum were collected in June 2017 by hand with self-contained underwater breathing apparatus (SCUBA) divers off the coast of Lanyu Island (Orchid Island), Taiwan. The samples were then stored in a $-20{ }^{\circ} \mathrm{C}$ freezer until extraction. A voucher specimen was deposited in the National Museum of Marine Biology and Aquarium, Taiwan (NMMBA-TW-SC-2017-418). Identification of the species of this organism was performed by comparison as described in previous publications [1-4].

\subsection{Extraction and Isolation}

The freeze-dried and sliced bodies (wet/dry weight $=1344 / 568 \mathrm{~g}$ ) of the specimen were extracted with supercritical $\mathrm{CO}_{2}$ to give $58.9 \mathrm{~g}$ of extract. Partial extract $(36.4 \mathrm{~g})$ was then applied on silica gel column and eluted with gradients of $n$-hexane/EtOAc to furnish fractions $\mathrm{A}-\mathrm{K}$. Fraction $\mathrm{F}$ was purified by NP-HPLC using a mixture of $n$-hexane/acetone (4:1) to yield fractions F1-F13. Fraction F6 was repurified by RP-HPLC, using a mixture of $\mathrm{MeOH} / \mathrm{H}_{2} \mathrm{O}(60: 40$; at a flow rate $=4 \mathrm{~mL} / \mathrm{min})$ to afford 4 $(6.7 \mathrm{mg})$. Fraction $\mathrm{G}$ was separated by NP-HPLC, using a mixture of $n$-hexane/acetone (3:1) to yield fractions G1-G12. Fractions G6 and G7 were repurified by RP-HPLC using a mixture of $\mathrm{MeOH} / \mathrm{H}_{2} \mathrm{O}$ 
(60:40; at a flow rate $=4.0 \mathrm{~mL} / \mathrm{min})$ to afford $5(1.3 \mathrm{mg})$ and $3(1.0 \mathrm{mg})$, respectively. Fraction $\mathrm{H}$ was separated by NP-HPLC using a mixture of $n$-hexane and acetone (3:1) to yield fractions H1-H18. Fractions $\mathrm{H} 12$ and $\mathrm{H} 15$ were repurified by RP-HPLC, using a mixture of $\mathrm{MeOH} / \mathrm{H}_{2} \mathrm{O}(60: 40$; at a flow rate $=4.0 \mathrm{~mL} / \mathrm{min})$ to afford $\mathbf{2}(2.1 \mathrm{mg})$ and $\mathbf{1}(0.6 \mathrm{mg})$, respectively.

Briarenol I (1): Amorphous powder; $[\alpha]_{\mathrm{D}}^{22}+207\left(c 0.03, \mathrm{CHCl}_{3}\right)$, IR (ATR) $v_{\max } 3524,1783,1736$, 1222, $891 \mathrm{~cm}^{-1} ;{ }^{13} \mathrm{C}\left(100 \mathrm{MHz}, \mathrm{CDCl}_{3}\right)$ and ${ }^{1} \mathrm{H}\left(400 \mathrm{MHz}, \mathrm{CDCl}_{3}\right) \mathrm{NMR}$ data (see Tables 1 and 2); ESIMS: $m / z 649$ [M + Na] ${ }^{+}$; HRESIMS $m / z 649.24677$ (calculated for $\mathrm{C}_{30} \mathrm{H}_{42} \mathrm{O}_{14}+\mathrm{Na}, 649.24668$ ).

Briarenol J (2): Amorphous powder; $[\alpha]_{\mathrm{D}}^{26}+140\left(c 0.08, \mathrm{CHCl}_{3}\right)$, IR (ATR) $v_{\max } 3483,1779,1727$, 1220, $890 \mathrm{~cm}^{-1} ;{ }^{13} \mathrm{C}\left(100 \mathrm{MHz}, \mathrm{CDCl}_{3}\right)$ and ${ }^{1} \mathrm{H}\left(400 \mathrm{MHz}, \mathrm{CDCl}_{3}\right) \mathrm{NMR}$ data (see Tables 1 and 2); ESIMS: $m / z 563[\mathrm{M}+\mathrm{Na}]^{+}$; HRESIMS $m / z 563.21007$ (calculated for $\mathrm{C}_{26} \mathrm{H}_{36} \mathrm{O}_{12}+\mathrm{Na}$, 563.20990).

Briarenol K (3): Amorphous powder; $[\alpha]_{\mathrm{D}}^{23}+37\left(c 0.06, \mathrm{CHCl}_{3}\right)$, IR (ATR) $v_{\max } 3468,1780,1739$, 1255, $892 \mathrm{~cm}^{-1} ;{ }^{13} \mathrm{C}\left(100 \mathrm{MHz}, \mathrm{CDCl}_{3}\right)$ and ${ }^{1} \mathrm{H}\left(400 \mathrm{MHz}, \mathrm{CDCl}_{3}\right) \mathrm{NMR}$ data (see Tables 1 and 2); ESIMS: $m / z 547[\mathrm{M}+\mathrm{Na}]^{+}$; HRESIMS $m / z 547.21514$ (calculated for $\mathrm{C}_{26} \mathrm{H}_{36} \mathrm{O}_{11}+\mathrm{Na}$, 547.21498).

Briaexcavatolide P (4): Amorphous powder; $[\alpha]_{\mathrm{D}}^{24}+182\left(c 0.3, \mathrm{CHCl}_{3}\right)$ (ref. [8], [ $\left.\alpha\right] 27 \mathrm{D}+167$ (c 1.0, $\left.\mathrm{CHCl}_{3}\right)$ ), IR (ATR) $v_{\max } 3513,1783,1731,1218,889 \mathrm{~cm}^{-1} ;{ }^{1} \mathrm{H}$ and ${ }^{13} \mathrm{C} \mathrm{NMR}$ data were found to be in agreement with previous study [8]; ESIMS: $m / z 633[\mathrm{M}+\mathrm{Na}]^{+}$.

Briaexcavatin P (5): Amorphous powder; $[\alpha]_{\mathrm{D}}^{23}+134\left(c 0.05, \mathrm{CHCl}_{3}\right)\left(\right.$ ref. $[9],[\alpha]_{\mathrm{D}}^{25}+198(c 0.08$, $\left.\mathrm{CHCl}_{3}\right)$ ), IR (ATR) $v_{\max } 3503,1785,1735,1240,889 \mathrm{~cm}^{-1} ;{ }^{1} \mathrm{H}$ and ${ }^{13} \mathrm{C}$ NMR data were found to be in agreement with previous study [9]; ESIMS: $m / z 605[\mathrm{M}+\mathrm{Na}]^{+}$.

\subsection{In Vitro Anti-inflammatory Assay}

The proinflammatory suppression assay was employed to assess the activities of the isolated compounds 1-5 against the release of iNOS and COX-2 from macrophage cells as the literature reported [13-15].

\section{Conclusions}

B. excavatum was demonstrated to have a wide structural diversity of briarane-type diterpenoids that possessed various pharmacological properties, especially in anti-inflammatory activity. In our continued study on B. excavatum, three previously unreported briaranes, briarenols I-K (1-3), along with the known analogues, briaexcavatolide $\mathrm{P}(4)$ and briaexcavatin $\mathrm{P}(5)$, were isolated. In the present study, the anti-inflammatory activity of $\mathbf{1 - 5}$ was assessed using inhibition of pro-inflammatory iNOS and COX-2 release from macrophages. The results indicated that briaexcavatolide $\mathrm{P}(4)$ showed the most potent suppressive effect on iNOS release.

Supplementary Materials: The Supplementary Materials are available online. ESIMS, HRESIMS, IR, 1D and 2D NMR spectra of new compounds 1-3.

Author Contributions: Conceptualization, L.-S.F., Y.-J.W., Z.-H.W. and P.-J.S; investigation, T.-H.H., Y.-H.C., B.-R.P., Y.-Y.C., L.-G.Z. and J.-J.C.; writing—original draft preparation, T.-H.H. and P.-J.S.; writing-review and editing, T.-C.L. and P.-J.S. All authors have read and agreed to the published version of the manuscript.

Funding: This research was supported by grants from the National Museum of Marine Biology and Aquarium; the National Dong Hwa University; and the Ministry of Science and Technology, Taiwan (Grant Nos: MOST 106-2320-B-291-001-MY3 and 107-2320-B-291-001-MY3) awarded to Ping-Jyun Sung.

Conflicts of Interest: The authors declare no conflicts of interest.

\section{References}

1. Bayer, F.M. Key to the genera of octocorallia exclusive of Pennatulacea (Coelenterata: Anthozoa), with diagnoses of new taxa. Proc. Biol. Soc. Wash. 1981, 94, 902-947.

2. Benayahu, Y.; Jeng, M.-S.; Perkol-Finkel, S.; Dai, C.-F. Soft corals (Octocorallia: Alcyonacea) from Southern Taiwan. II. Species diversity and distributional patterns. Zool. Stud. 2004, 43, 548-560.

3. Miyazaki, Y.; Reimer, J.D. Morphological and genetic diversity of Briareum (Anthozoa: Octocorallia) from the Ryukyu Archipelago, Japan. Zool. Sci. 2014, 31, 692-702. [CrossRef] [PubMed] 
4. Samimi-Namin, K.; van Ofwegen, L.P. Overview of the genus Briareum (Cnidaria, Octocorallia, Briareidae) in the Indo-Pacific, with the description of a new species. Zookeys 2016, 557, 1-44. [CrossRef] [PubMed]

5. Su, Y.-D.; Su, J.-H.; Hwang, T.-L.; Wen, Z.-H.; Sheu, J.-H.; Wu, Y.-C.; Sung, P.-J. Briarane diterpenoids isolated from octocorals between 2014 and 2016. Mar. Drugs 2017, 15, 44. [CrossRef] [PubMed]

6. Hu, C.-C.; Lin, N.-C.; Peng, B.-R.; Chen, Y.-Y.; Wen, Z.-H.; Chang, Y.-C.; Lee, G.-H.; Wu, Y.-C.; Sung, P.-J. New trihydroxybriarane diterpenoids from an octocoral Briareum sp. Phytochem. Lett. 2020, 35, 23-27. [CrossRef]

7. Molina, S.L.; Forero, A.M.; Ayala, F.I.; Puyana, M.; Zea, S.; Castellanos, L.; Muñoz, D.; Arboleda, G.; Sandoval-Hernández, A.G.; Ramos, F.A. Metabolic profiling of the soft coral Erythropodium caribaeorum (Alcyonacea: Anthothelidae) from the Colombian Caribbean reveals different chemotypes. Mar. Drugs 2020, 18, 4. [CrossRef] [PubMed]

8. Wu, S.-L.; Sung, P.-J.; Chiang, M.Y.; Wu, J.-Y.; Sheu, J.-H. New polyoxygenated briarane diterpenoids, briaexcavatolides O-R, from the gorgonian Briareum excavatum. J. Nat. Prod. 2001, 64, 1415-1420. [CrossRef] [PubMed]

9. Sung, P.-J.; Lin, M.-R.; Hwang, T.-L.; Fan, T.-Y.; Su, W.-C.; Ho, C.-C.; Fang, L.-S.; Wang, W.-H. Briaexcavatins $\mathrm{M}-\mathrm{P}$, four new briarane-related diterpenoids from cultured octocoral Briareum excavatum (Briareidae). Chem. Pharm. Bull. 2008, 56, 930-935. [CrossRef] [PubMed]

10. Sheu, J.-H.; Sung, P.-J.; Cheng, M.-C.; Liu, H.-Y.; Fang, L.-S.; Duh, C.-Y.; Chiang, M.Y. Novel cytotoxic diterpenes, excavatolides A-E, isolated from the Formosan gorgonian Briareum excavatum. J. Nat. Prod. 1998, 61, 602-608. [CrossRef] [PubMed]

11. Yao, J.-W.; Chi, W.-C.; Lee, G.-H.; Su, J.-H.; Hwang, T.-L.; Wu, Y.-J.; Su, T.-R.; Sheu, J.-H.; Sung, P.-J. 2-Acetoxybriaranes from Briareum violaceum. Tetrahedron 2019, 75, 3751-3757. [CrossRef]

12. Pordesimo, E.O.; Schmitz, F.J.; Ciereszko, L.S.; Hossain, M.B.; van der Helm, D. New briarein diterpenes from the Caribbean gorgonians Erythropodium caribaeorum and Briareum sp. J. Org. Chem. 1991, 56, 2344-2357. [CrossRef]

13. Jean, Y.-H.; Chen, W.-F.; Sung, C.-S.; Duh, C.-Y.; Huang, S.-Y.; Lin, C.-S.; Tai, M.-H.; Tzeng, S.-F.; Wen, Z.-H. Capnellene, a natural marine compound derived from soft coral, attenuates chronic constriction injury-induced neuropathic in rats. Br. J. Pharmacol. 2009, 158, 713-725. [CrossRef] [PubMed]

14. Jean, Y.-H.; Chen, W.-F.; Duh, C.-Y.; Huang, S.-Y.; Hsu, C.-H.; Lin, C.-S.; Sung, C.-S.; Chen, I.-M.; Wen, Z.-H. Inducible nitric oxide synthase and cyclooxygenase-2 participate in anti-inflammatory and analgesic effects of the natural marine compound lemnalol from Formosan soft coral Lemnalia cervicorni. Eur. J. Pharmacol. 2008, 578, 323-331. [CrossRef] [PubMed]

15. Chen, L.-C.; Lin, Y.-Y.; Jean, Y.-H.; Lu, Y.; Chen, W.-F.; Yang, S.-N.; Wang, H.-M.D.; Jang, I.-Y.; Chen, I.-M.; $\mathrm{Su}, \mathrm{J} . \mathrm{-H}$; ; et al. Anti-inflammatory and analgesic effects of the marine-derived compound comaparvin isolated from the crinoid Comanthus bennetti. Molecules 2014, 19, 14667-14686. [CrossRef] [PubMed]

(C) 2020 by the authors. Licensee MDPI, Basel, Switzerland. This article is an open access article distributed under the terms and conditions of the Creative Commons Attribution (CC BY) license (http://creativecommons.org/licenses/by/4.0/). 